\title{
BIOLOGICAL CONTROL OF TETRANYCHUS URTICAE KOCH ON WATERMELON IN OPEN FIELD AND GREENHOUSE BY USING THE PREDATORY MITE SPECIES PHYTOSEIULUS PERSIMILIS (A.-H.)
}

\author{
ABD EL-WAHED, N. M., K. M. EL-SAYED AND MONA S. EL-GHOBASHI
}

Plant Protection Research Institute, ARC, Dokki, Giza

(Manuscript received 9 July 2009)

\begin{abstract}
Biological control of the two-spotted spider mite, Tetranychus urticae Koch in Behera Governorate on watermelon field and greenhouse are possible by using the predatory mite, Phytoseiulus persimilis (A.-H.). The predacious mite was released at three levels 20,30 and 40 individuals/bit in open field, while was released in greenhouse at one level with 30 individuals/bit, the best one in the level C (40 individuals/bit) followed by B and A levels, respectively. The percent reduction of $T$. urticae population in open field reached $98.25 \%$ after seven weeks from released at level C (40 individuals/bit), while reached 94.82 and $92.38 \%$ at levels $B$ and $A$, respectively. The reduction percentage of $T$. urticae in greenhouse at rate 30 individuals/bit was $98.83 \%$ in the end of experiment. This results indicated that the possibility of this predator to control T. urticae on watermelon in open field and greenhouse.
\end{abstract}

\section{INTRODUCTION}

The two spotted-spider mite, Tetranychus urticae Koch is one of the serious mite pests, which infesting watermelon cussing several damage for leaves and reduction of the quality and quantity of the production.

Watermelon is considered an important vegetable eaten fresh. The whole cultivated area in Egypt reached about 118,544 feddan, which producing 1,485,939 tons, with mean production rate 12,5 ton/feddan (Statistical Institute 2008).

The present work aim to using the biocontrol agent by predatory mite, $P$. persimilis for reduction $T$. urticae on watermelon in open field and greenhouse. P. persimilis was released by several authors to control this pest on certain plants, Decou (1994), Watanabe et al. (1994), Ramos and Rodriguez (1995), Heikal anf Mowafi (1998), Heikal and Fawzy (2002), Heikal et al. (2004) and Fawzy et al. (2004\&2006).

\section{MATERIALS AND METHODS}

\section{Predator's source}

Population of the predatory mite, Phytoseiulus persimilis (A.-H.) was reared in the laboratory on bean plants leaves (Phaseolus vulgaris L.), while mass rearing on the two-spotted spider mite, Tetranychus urticae Koch on bean plants in a greenhouse 
$60 \times 90 \mathrm{~m}^{2}$ about $540 \mathrm{~m}^{2}$ according the technique followed by El-Halawany et al. (2000).

\section{Experiments design}

The area of the field experiment was about one feddan, but the greenhouse experiment was about $60 \times 90 \mathrm{~m}^{2}$ at Benha in Qualiobia Governorate, the two experiments were left without any pesticide treatments. In field, the predatory mite was released in three treatments (A, B and C) with rates of 20, 30 and 40 individuals/bit, respectively. Whereas, in greenhouse only one treatment was released at level 30 individuals/bit and control left without release.

Samples contain 10 leaves were randomly taken from each treatment before and after release, weekly samples were taken and examined in field using hand lens (20X).

The reduction of $T$. urticae populations were calculated according to the equation of Henderson and Tilton (1955).

\section{RESULTS AND DISCUSSION}

\section{In open field}

Data in Table (1) revealed that, when the predatory mite, Phytoseiulus persimilis (A.-H.) released in open field at three levels $(A, B$ and $C)$, the best one is $C$ treatment (40 individuals/bit) followed by $B$ (30 individuals/bit), while the last level was A treatment (20 individuals/bit).

Pre releasing counts of $T$. urticae were 13.4, 12.2 and 13.9 moving stages/leaf in A, B and C, respectively, compared with control, which reached to 11.8 moving stages/leaf.

The reduction percentage in level $\mathrm{C}$ increased gradually beginning of $53.86 \%$ in the first week followed by $70.37,78.38$ and $88.93 \%$ in the second, third and fourth weeks, respectively, reached to $98.25 \%$ in the seventh week. On the other hand, in level $B$ the percent reduction beginning with $39.02 \%$ in the first week, after that the reduction increased gradually to $59.10,65.15,77.98,89.74$ and $91.68 \%$ in the second, third, fourth, fifth and sixth weeks, respectively, reached to $94.82 \%$ in the seventh week.

The reduction percentage was lowest in level $A$, the reduction beginning with $41.29 \%$ in the first week after that the reduction increased gradually until reached to $92.38 \%$ in the seventh week (Table 1). 


\section{In greenhouse}

Data in Table (2) revealed that, when the predatory mite, $P$. persimilis released in greenhouse with only one level (30 individuals/bit), the reduction percentage was better than the level C (40 individuals/bit) in open field treatment.

Table 1. Release the predatory mite, Phytoseiulus persimilis for controlling the twospotted spider mite, Tetranychus urticae on watermelon in open field.

\begin{tabular}{|c|c|c|c|c|c|c|}
\hline \multirow{3}{*}{ Sampling date } & \multirow{3}{*}{ Treatment } & \multicolumn{3}{|c|}{$\begin{array}{c}\text { Number and reduction } \% \text { of moving } \\
\text { stages of } T \text {. urticae/ } 10 \text { leaves }\end{array}$} & \multicolumn{2}{|c|}{ P. persimilis } \\
\hline & & \multicolumn{2}{|c|}{ Number } & \multirow{2}{*}{ Reduction \% } & \multirow{2}{*}{ Total } & \multirow{2}{*}{$X^{\prime} /$ leaf } \\
\hline & & Total & $x^{\prime} /$ leaf & & & \\
\hline \multirow{3}{*}{ Jan., 3, 2009} & (A) 20 individuals & 134 & 13.4 & - & - & - \\
\hline & (B) 20 individuals & 122 & 12.2 & - & - & - \\
\hline & (C) 20 individuals & 139 & 13.9 & - & - & - \\
\hline Pre-count & (D) No release & 118 & 11.8 & - & - & - \\
\hline \multirow{3}{*}{ Jan., 10} & (A) 20 individuals & 92 & 9.2 & 41.29 & 31 & 3.1 \\
\hline & (B) 20 individuals & 87 & 8.7 & 39.02 & 34 & 3.4 \\
\hline & (C) 20 individuals & 75 & 7.5 & 53.86 & 41 & 4.1 \\
\hline $1^{\text {st }}$ Post-count & (D) No release & 138 & 13.8 & - & - & - \\
\hline \multirow{3}{*}{ Jan., 17} & (A) 20 individuals & 78 & 7.8 & 53.90 & 37 & 3.7 \\
\hline & (B) 20 individuals & 63 & 6.3 & 59.10 & 45 & 4.5 \\
\hline & (C) 20 individuals & 52 & 5.2 & 70.37 & 56 & 5.6 \\
\hline $2^{\text {nd }}$ Post-count & (D) No release & 149 & 14.9 & - & - & - \\
\hline \multirow{3}{*}{ Jan., 24} & (A) 20 individuals & 71 & 7.1 & 61.17 & 22 & 2.2 \\
\hline & (B) 20 individuals & 58 & 5.8 & 65.15 & 46 & 4.6 \\
\hline & (C) 20 individuals & 41 & 4.1 & 78.38 & 61 & 6.1 \\
\hline $3^{\text {rd }}$ Post-count & (D) No release & 161 & 16.1 & - & - & - \\
\hline \multirow{3}{*}{ Jan., 31} & (A) 20 individuals & 61 & 5.1 & 70.81 & 42 & 4.2 \\
\hline & (B) 20 individuals & 42 & 3.2 & 77.98 & 51 & 5.1 \\
\hline & (C) 20 individuals & 24 & 2.4 & 88.93 & 63 & 6.3 \\
\hline $4^{\text {th }}$ Post-count & (D) No release & 184 & 18.4 & - & - & - \\
\hline \multirow{3}{*}{ Feb., 7} & (A) 20 individuals & 34 & 3.4 & 84.87 & 45 & 4.5 \\
\hline & (B) 20 individuals & 21 & 2.1 & 89.74 & 44 & 4.4 \\
\hline & (C) 20 individuals & 16 & 1.6 & 93.14 & 78 & 7.8 \\
\hline $5^{\text {th }}$ Post-count & (D) No release & 198 & 19.8 & - & - & - \\
\hline \multirow{3}{*}{ Feb., 14} & (A) 20 individuals & 22 & 2.2 & 91.23 & 65 & 6.5 \\
\hline & (B) 20 individuals & 19 & 1.9 & 91.68 & 86 & 8.6 \\
\hline & (C) 20 individuals & 11 & 1.1 & 95.77 & 102 & 10.2 \\
\hline $6^{\text {th }}$ Post-count & (D) No release & 221 & 22.1 & - & - & - \\
\hline \multirow{3}{*}{ Feb., 21} & (A) 20 individuals & 21 & 1.6 & 92.38 & 71 & 7.1 \\
\hline & (B) 20 individuals & 13 & 0.9 & 94.82 & 98 & 9.8 \\
\hline & (C) 20 individuals & 5 & 0.5 & 98.25 & 114 & 11.4 \\
\hline $7^{\text {th }}$ Post-count & (D) No release & 243 & 24.3 & - & - & - \\
\hline
\end{tabular}


Table 2. Release the predatory mite, Phytoseiulus persimilis for controlling the twospotted spider mite, Tetranychus urticae on watermelon in greenhouse.

\begin{tabular}{|c|c|c|c|c|c|c|c|}
\hline \multirow{2}{*}{ Sampling date } & \multicolumn{9}{|c|}{ Number and reduction\% of moving stages of $T$ urticae/10 leaves } & \multicolumn{2}{c|}{ P. persimilis } \\
\cline { 2 - 7 } & \multicolumn{2}{|c|}{ Release area } & \multicolumn{2}{c|}{ Control } & \multirow{2}{*}{ Total } & X'/leaf \\
\cline { 2 - 7 } & Total & X /leaf & Reduction\% & Total & X'/leaf & & \\
\hline \multirow{2}{*}{ Feb., 10, 2009 } & 151 & 15.1 & - & 126 & 12.6 & - & - \\
\hline Feb., 17 & 112 & 11.2 & 44.37 & 168 & 16.8 & 37 & 3.7 \\
\hline Feb., 24 & 79 & 7.9 & 67.20 & 201 & 20.1 & 61 & 6.1 \\
\hline March 3 & 56 & 5.6 & 79.77 & 231 & 23.1 & 64 & 6.4 \\
\hline March 10 & 41 & 4.1 & 88.08 & 287 & 28.7 & 69 & 6.9 \\
\hline March 17 & 24 & 2.4 & 94.19 & 345 & 34.5 & 86 & 8.6 \\
\hline March 24 & 16 & 1.6 & 96.58 & 391 & 39.1 & 112 & 11.2 \\
\hline April 2 & 6 & 0.6 & 98.83 & 428 & 42.8 & 139 & 13.9 \\
\hline
\end{tabular}

The pre releasing counts of $T$. urticae averaged 9.6 moving stages/leaf compared with 8.4 moving stages/leaf in control.

The reduction percentage of $T$. urticae after one week of release was $43.57 \%$ increased gradually to reach $98.83 \%$ in the end of the experiment. This might be due to the greenhouse conditions (temperature and relative humidity) are suitable for density and effectiveness of the predatory mite against the two-spotted spider mite, so this predator became more effective inside the greenhouse (Table 2).

\section{REFERENCES}

1. Decou, G. C. 1994. Biological control of the two-spotted spider mite (Acarina : Tetranychidae) on commercial strawberries in Florida with Phytoseiulus persimilis (Acarina : Phytoseiidae). Fla. Entomol., 77 (1): 33-41.

2. El-Halawany, M. E., M. A. Abd El-Samad and H. M. Ebrahim. 2000. Biological control of the spider mite, Tetranychus urticae Koch by the phytoseiid mite, Phytoseiulus persimilis (A.-H.) compared with chemical control. Bull. Ent. Soc. Egypt, Econ. Ser., 27 (63).

3. Fawzy, M. M. H., N. M. Abd El-Wahed and K. M. El-Sayed. 2004. Biological control of the two-spotted spider mite (Acari: Tetranychidae) with Phytoseiulus persimilis (Acari : Phytoseiidae) on comercial cucumber in Sharkia Governorate. Annal. Agric. Sci., Moshtohor 42 (1): 357-364.

4. Fawzy, M. M. H., Mona S. El-Gobashi and N. M. Abd El-Wahed. 2006. Biological control of the two-spotted spider mite, Tetranychus urticae Koch by phytoseiid mite, Phytoseiulus persimilis (A.-H.) in cantaloupe field in Sharkia Governorate (Acari : Phytoseiidae : Tetranychidae). J. Agric. Res., 84 (2): 355-362. 
5. Heikal, I. H. and M. M. H. Fawzy. 2002. A preliminary study on biological control of Tetranychus urticae Koch on cucumber (Acari : Tetranychidae). Egypt. J. Agric. Res., 81 (1): 93-100.

6. Heikal, I. H. and M. H. Mowafi. 1998. Biological control of Tetranychus urticae on bean plants by two introduced predators. Al-Azhar J. Agric. Res., 27: 185-196.

7. Heikal, I. H., M. M. H. Fawzy and K. E. M. El-Sayed. 2004. A preliminary study on releasing Phytoseiulus macropilis (Banks) in cantaloupe field to control Tetranychus urticae Koch. Egypt. J. Agric. Res., 82 (2): 595-605.

8. Hendrson, C. F. and E. W. Tilton. 1955. Test with acaricides against the brown wheat mite., J. Econ Entomol., $48:$ 157-161.

9. Statistical Institute. 2008. Final report about watermelon in Egypt.

10. Ramos, M. and H. Rodriguez. 1995. Efficiency of control to Tetranychus tumidus (Banks) by Phytoseiulus macropilis (Banks) in banana I. Greenhouse trials. Revista de Protection Vegetal., 10: 207-211.5.

11. Watanabe, M. A., G. J., De Morales, J. I. R. J. Gastal do and G. Nicolella. 1994. Biological control of two-spotted spider mite with predatory phytoseiids (Acari : Tetranychidae : Phytoseiidae). Scientia Agricola, 51 (1): 75-81. 
Tetranychus urticae Koch المكافحة الحيوية للعنكبوت الأحمر العادي

علي البطيخ في الحقل والصوية بإستخدام المفترس الأكاروسي الإسي

\section{Phytoseiulus persimilis (A.-H.)}

نزيه محمد عبد الواحد ، كرم السبد محمد ، مني سليمان الغباشي

$$
\text { معطُ بحوث وقاية النباتات - مركز البحوث الزراعية - الدقي - الجيزة }
$$

تم إطلاق المفترس الأكاروسي Phytoseiulus persimilis لمكافحة العنكبوت الأحمر العادي Tetranychus urticae

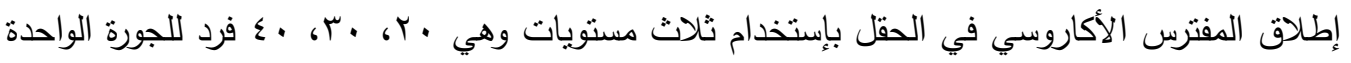
وأوضحت النتائج أن المستوي الثالث ـع فرد للجورة هو الأفضل حيث اعطى نسبة خفض في في التعداد

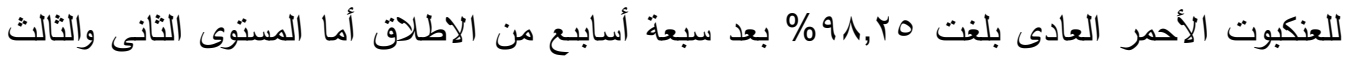

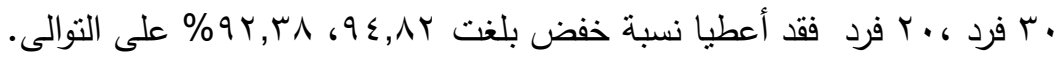

أما بالنسبة للصوبة فقد تم استخدام مستوى واحد للاطلاق وهو ـ فرد للجورة و قد أعطى

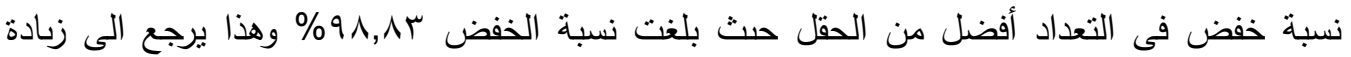

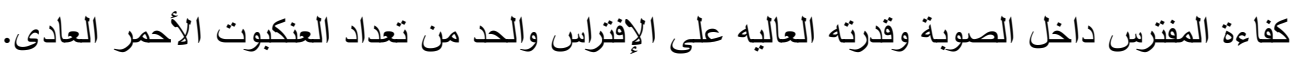

